\title{
The T-Shape Dilemma in the Industrial Engineering and Management
}

\author{
Sigal Koral Kordova, Moti Frank \\ Holon Institute of Technology (Israel) \\ sigalkord@gmail.com,frankm@bit.ac.il
}

Received: September 2013

Accepted: September 2014

\section{Abstract:}

Purpose: This paper concerns the undergraduate "Industrial Engineering and Management" curriculum. The purpose of the research was to examine the extent to which there is in-depth coverage of teaching/learning in the combined field of industrial engineering and management, as opposed to breadth in multidisciplinary teaching/learning in this field (the T-shaped dilemma). In line with this aim, the following research question was derived: With respect to the breadth of multidisciplinary teaching and the depth of teaching in industrial engineering and management, what is the desired situation as opposed to the actual situation?

Design/methodology/approach: To examine the T-shaped dilemma, 16 in-depth interviews were conducted with senior-level managers in industry, and with leading academics in the fields of industrial engineering and management. The interviewees were asked questions regarding the planning and design of the curriculum in these fields. The analysis of the interviews was carried out by ascribing categories to the data, and presenting the categories with the highest frequencies in all of the interviews.

Findings and originality/value: One of the most significant results was the considerable variability between the answers of senior-level managers in industry and those of the academics. Whereas individuals in the business field (senior-level managers) place great importance on focusing on the management/business aspect and the acquisition of multidisciplinary knowledge, academics emphasize the importance of understanding the theories and rationale behind the material studied, studying the basic principles and thus 
acquiring a strong theoretical foundation, the implementation of which is then expressed in diverse applications.

Research limitations/implications: Owing to time constraints, the research only included 16 in-depth interviews. In order to increase the external validity of this research, more interviews should be executed.

Originality/value: The framework of this research is unique in terms of the topic and analytic processes.

Keywords: t-shape dilemma, integrative approach, knowledge management, learning organization

\section{Introduction}

Today's business environment is the result of considerable technological, social and economic changes. This environment is characterized by the globalization of the world economy, fierce inter-organizational competition, the use of innovative management approaches, and the availability of information and knowledge through access to rapid and cheap media and advanced information systems.

The recently evolving economic and industry changes and developments must also be taken into account to update and adapt the industrial engineering and management curriculum as graduates in this field will be integrated into the competitive market upon completion of their studies. Industrial engineering and management study areas are based on the implementation of engineering, scientific and technological principles. The studies span a wide range of areas to enable graduates to cope with the many challenges ahead in industry, research and development.

In recent years, all aspects of industry have become central to our modern lifestyles and are very influential in a highly-developed world. As a result, industrial engineering and management graduates require better training and preparation than in the past. They must be proficient in the many new technologies and capable of handling complex information systems. The industrial engineering curriculum combines classic engineering tools, based on mathematical principles, with tools from "soft" areas, such as human resources management and psychology, to increase the efficiency of processes in which the human factor is involved. Today, industrial engineers integrated in many areas and deal with varied fields, starting with the development of robots, through integration into project teams, up to the holding of diverse managerial positions.

In this study, the T-shape dilemma was examined with regard to teaching in the field of industrial engineering and management. This dilemma relates to the extent to which there 
should be a focus on the depth of teaching/learning - in this case, concerning engineering content in the industrial engineering and management discipline - (represented by the vertical part of the letter $T$ in Figure 1), as opposed to a focus on the breadth of coverage in multidisciplinary teaching/learning (represented by the horizontal part of the letter $\mathrm{T}$ in Figure 1).

The horizontal part of the letter T represents the breadth of multidisciplinary teaching/learning

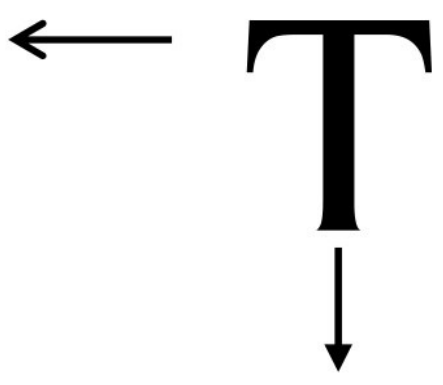

The vertical part of the letter $\mathrm{T}$ represents the depth of teaching/learning

Figure 1. The T-shape dilemma

The balance between depth and breadth in learning in the industrial engineering and management discipline is a bone of contention among the community of researchers in this area, and to date, there have been no unequivocal answers in terms of which - if either should predominate. For example, many still believe that in teaching too much emphasis is placed on the horizontal part of the T shape (breadth), thus focusing on learning a little about a lot. In contrast, a growing number of individuals believe that based on data from the field, the industrial engineering and management discipline represents an important body of knowledge, which enables graduates to integrate successfully into defined positions in the industry. Following the presentation of the findings of this study, there will be a detailed discussion on this important issue, presenting the different aspects rather than taking a stand. The main, practical contribution of this study is to identify principles for planning an industrial engineering and management undergraduate curriculum that would suit teaching with the desired focus (breadth or depth). 


\subsection{The T-shape approach}

The T-shape dilemma has been discussed extensively among researchers dealing with the area of knowledge management in organizations. Knowledge management concerns the acquisition, development, and dissemination of organizational knowledge, and the optimal utilization of this knowledge. Knowledge, as a social construct, can be considered the result of reciprocal action (Hitt, Ireland \& Hoskisson, 2001). Knowledge is neither information nor data. Data are objective facts presented without any judgment or context. Data that have been classified according to type, analyzed, and summarized, and then integrated into specific contexts, become information. Information, which is data that have relevance to an objective, is perceived as a competitive and valuable resource by companies. Information develops into more relevant knowledge, competitively speaking, when it is used to form valuable market ties. Therefore, knowledge is information enriched with experience, judgment, intuition, and values. Ultimately, most knowledge is inherent in the employees themselves. For this reason, successful organizations constantly provide their employees with many opportunities to enrich the data and information at their disposal. Knowledge management deals with identifying valuable organizational knowledge that exists within a company. This knowledge should be cataloged to enable its efficient dissemination and continuous use by all units within the company. Developing an "organizational memory" through such actions improves the company's ability to adopt knowledge and to apply it in varying environmental conditions.

In the field of knowledge management, Nonaka and Takeuchi (1995) identify a four-stage spiral model of organizational learning, in which knowledge flows through a company by means of four interconnected processes. These four processes are the main ways of managing organizational knowledge. Socialization is the process of conveying tacit personal knowledge to others. One can acquire tacit knowledge by observation and practice alone. Therefore, companies employ knowledge management methods, such as using instructors and mentors, to help employees transfer their abilities to one another through observation and practice. Externalization is the process by which tacit knowledge is converted into explicit ideas. In many cases, questions help to express implied and complex knowledge in more structured terms. Combination relates to the study of information systems found among different people. The objective of combination is to combine implied and unique knowledge systems to create explicit knowledge, enabling its dissemination throughout the entire company. Through internalization, company employees absorb explicit knowledge created through socialization, externalization and combination. Via this new explicit knowledge, employees develop new implied knowledge: knowledge that starts another round of the knowledge management process, involving the four stages mentioned above.

According to Hedlund (1994), the T-shape approach relates to increasing knowledge in two ways: either through enrichment, or expansion. Enriching knowledge takes place when the existing knowledge is "stretched" vertically. In other words, original bodies of knowledge are 
subjected to an in-depth examination, with the intention of gaining greater understanding or clarification. Included in this category are most cases of upgrading knowledge. On the other hand, expanding knowledge takes place when the existing knowledge is expanded horizontally; that is, the original knowledge bases are integrated and become diverse. The knowledge created through the processes of socialization, externalization, combination, and internationalization (Nonaka \& Takeuchi, 1995) sparks the creation of a new spiral of knowledge that expands both horizontally and vertically. This is a dynamic process that starts at the individual level, continues to the departmental and unit level, and finally arrives at the upper limits of the organization. The shorter the recycling period of the lifespan of knowledge, the more essential is its expansion (Sanchez \& Heene, 1997). Expanding knowledge could include several actions: leading the organization to enrich and expand its knowledge using existing core knowledge, and supporting the expansion/enrichment of knowledge through transfer, integration, change, and refinement.

In light of the changes taking place in the business world, and in accordance with the great importance of knowledge management in organizations, teaching/learning processes stemming from the connection of academia to a knowledge society should be characterized anew. Information and knowledge revolutions in the business world, and their extensive implementation in all aspects of our lives, also leave their impression on institutes of higher education in general and on curricula in particular.

This study examines the T-Shape dilemma and the approach to knowledge creation in the field of industrial engineering and management, including how it is implemented in curriculum planning.

\subsection{An integrative teaching/learning approach in industrial engineering and management}

Learning through a disciplinary approach is achieved by looking through a zoom lens, as it were, whereas learning through an integrative approach occurs by looking through a wideangle lens (Travaslaky, 2006). An integrative approach considers the whole as opposed to individual parts, and emphasizes the "less is more" notion. The advantages of an integrative approach in planning the industrial and systems engineering curriculum are expressed in the study environment. Such an approach enables learners to research and discover the connections between different areas of knowledge (Fogarty, 1991), and develop their ability to become familiar with and function within their environment (Blum, 1991), fosters cooperation between teachers, and encourages professional development.

In the research literature, three models for planning learning using an integrative approach are presented: the multidisciplinary model, the interdisciplinary model, and the transdisciplinary 
model. These models differ from one another in terms of how they relate different areas of knowledge to each other. In the multidisciplinary model, each area of knowledge preserves its uniqueness and describes the subject from a specific disciplinary perspective. In this model, there is no breach in the framework of knowledge areas, but rather efforts are made to illustrate a common subject through each of the knowledge areas (Travaslaky, 2006). The interdisciplinary model strives to break down the boundaries that differentiate the different knowledge areas, focusing on common and relevant aspects in relation to a particular subject (Alpert, 2002; Fogarty, 1991). The transdisciplinary model differs from the other two models in that it bases the building of the curriculum on information and knowledge that are relevant to reality and on finding unique ways in which to create cultural, social and intellectual connections to location/place, time and people. Hence, this model offers the greatest freedom for flexible, dynamic and interactive planning (Travaslaky, 2006). The point of departure of both the multidisciplinary and interdisciplinary models is the discipline, whereas the point of departure of the transdisciplinary model is the individuals and their world.

The model employed most frequently in the industrial engineering and management curriculum is the interdisciplinary model; through this, a connection is made between different areas of knowledge in the discipline, such as statistics, quality management, and production systems management. The goal is to create a curriculum that focuses on subjects common to the different knowledge areas.

\section{Research methodology}

In this study, 16 semi-structured interviews in total were undertaken with leading academics from the industrial engineering and management discipline, and senior managers in the industry. The seven academics all had extensive experience in mentoring final projects, as well as professional experience in diverse specializations (production, marketing, project management, accounting, business administration). The nine industry managers all held key positions in the business field, including CEOs, a headquarters manager, a private consulting firm owner, a service manager, and a business development manager. Hence, their areas of professional specialization were varied; this was intentional, an aimed to gain the perceptions of as wide a range of individuals as possible, in particular, holding managerial positions in diverse industries (high-tech and traditional) and from different areas of specialization, not necessarily from the industrial engineering and management discipline. Nevertheless, it is important to point out that all of the managers interviewed were in direct or indirect contact with industrial engineering engineers; some were even extremely familiar with the industrial engineering and management academic curriculum.

The interviews were semi-structured, which enabled the revelation or inclusion of information concerning matters that could not have been predicted in advance, as well as obtaining 
information on specific topics defined in the research questions. The interview questions related to teaching/learning in the industrial engineering and management discipline, as well as graduates' entry into the job market. The main questions asked were as follows:

- Should the planning and design of the industrial engineering and management curriculum focus on the graduates' practical training, prior to their future integration into knowledge-intensive industries, or on enriching their theoretical and research knowledge?

- To what extent does the teaching/learning of industrial engineering and management discipline emphasize breadth in multidisciplinary learning or depth of learning?

- How might the industrial engineering and management curriculum respond to the needs of medium- and senior-level managers in knowledge-intensive industries, and in parallel, impart technological knowledge and research capabilities, while emphasizing the engineering-technological side of the field?

- To what extent should the industrial engineering and management curriculum be based on a scientific or engineering background, a basic understanding of advanced technologies, the study of tools and methods for analyzing processes in technology-rich organizations, and on training for varied senior-level positions with a practical and/or research character in this field? What is the role of each of the above in the curriculum?

- Do graduates in the industrial engineering and management discipline provide a good enough response to the needs of medium- and senior-level managers in high-tech industries, or is there a preference at these levels for graduates from "pure" engineering disciplines, such as computer science or electronics?

- How are graduates in the industrial engineering and management discipline integrated into advanced industries?

- Is there an advantage to either breadth or depth of study in the industrial engineering and management discipline, in particular? And should the curriculum for every field focus on a certain area and enrich it, or include many fields (i.e., knowing a lot about a little, or a little about a lot)?

The interview data were transcribed and the interviewees' responses were categorized to enable the identification of prominent topics or themes, based on seeking out patterns, repetition, comparison and contradictions. This was done in order to create as full a picture as possible about the reality being studied. To ensure the objectivity, reliability and validity of research, the findings must be trustworthy. In this study, triangulation was employed, crossreferencing sources to validate the information provided in the different interviews. Thus, the 
findings presented here are those that are especially salient in the data and representative of the interviewees' perspectives; that is, similar statements were made by at least three interviewees.

\section{Research findings}

Table 1 summarizes the main categories found in all 16 semi-structured interviews on the subject of the T-shaped dilemma. The table presents the frequency with which each category was found in the data obtained from the seven academics, compared to the data from the nine senior-level managers (a total of 77 categories).

\begin{tabular}{|c|l|l|c|c|c|}
\hline \multirow{2}{*}{ No. } & \multicolumn{1}{|c|}{ Main category } & \multicolumn{1}{c|}{ Subcategory examples } & $\begin{array}{c}\text { Business } \\
\text { Managers }\end{array}$ & Academics & Total \\
\hline 1 & $\begin{array}{l}\text { Manager/ } \\
\text { management level } \\
\text { in the organization }\end{array}$ & $\begin{array}{l}\text { Business manager, systemic aspects/view, } \\
\text { managerial aspects/tools, initiative and curiosity, } \\
\text { thinking flexibility, business thinking, asking } \\
\text { questions, critical factors, learning ability, } \\
\text { emotional intelligence, cognitive aspects }\end{array}$ & 400 & 79 & 479 \\
\hline 2 & Organizational level & $\begin{array}{l}\text { Traditional vs. advanced industries, time to } \\
\text { market, marketing, systemic view as part of the } \\
\text { organization's goals, operational aspect }\end{array}$ & 15 & 4 & 19 \\
\hline 3 & Student level & $\begin{array}{l}\text { Specialization at work, integrating graduates into } \\
\text { the market, independent learning, research ability, } \\
\text { personality qualities }\end{array}$ & 29 & 31 & 60 \\
\hline 4 & Curriculum level & $\begin{array}{l}\text { Theoretical aspect, business reality aspect, } \\
\text { professional breadth, broad learning, systems } \\
\text { thinking training, practical tools, general learning, } \\
\text { behavioral sciences, managerial training, core } \\
\text { areas, technological basis, knowing a lot about a } \\
\text { lot, up-to-date curriculum, ability to think }\end{array}$ & 137 & 115 & 252 \\
\hline
\end{tabular}

Table 1. T-Shape dilemma: Interview response categories

Comparing the two interviewed groups, a marked difference can be observed with respect to the attitudes of the interviewees concerning the core principles of the industrial engineering and management discipline. The managers place great importance on focusing studies on the managerial-business aspects and acquiring multidisciplinary knowledge. In contrast, the academics highlight the importance of understanding the theories and rationale of the material being studied, imparting a firm theoretical basis, and studying the basic principles through which applications are expressed by the intelligent use of tools in the field.

Despite the differences of opinion among the interviewees, there was also agreement on many topics. All of the interviewees pointed to the importance of connecting the study of the industrial engineering and management discipline with the business reality, and the importance of exposure to business aspects beyond the theoretical aspects of the study process. The 
teaching/learning of industrial engineering and management is considered to focus on the breadth of study, during which learners examine operational-organizational processes. However, unlike learning processes in pure engineering areas, in which decision-making processes are based on facts and data, in the business world, decisions are sometimes based on feelings, recognizing opportunities, intuition, taking risks, etc. Therefore, graduates require creative and flexible thinking skills. The respondents considered that the focus of the learning process should be placed more on managerial-business aspects and less on technicalengineering aspects. An analysis of the different interviews showed agreement regarding this issue, as all of the interviewees claimed that the education of industrial engineering and management engineers must include training for managerial positions, and provide relevant business tools for the business world.

In relation to the industrial engineering and management curriculum, the interviewees highlighted the following aspects:

- Industrial engineering and management is not a pure engineering field like electronics or electricity. The student learns many non-engineering subjects.

- The curriculum should include diverse fields, the common denominator of which is the ability to influence processes to help an organization meet its goals and improve performance.

- For individuals who will be dealing with management in the future, breadth of training is very important for their integration into the job market.

- With regard to the curriculum, emphasis must be placed on personal, financial and legal aspects, and the ability to motivate employees.

- The curriculum must include engineering tools and courses in quantitative subjects, such as statistics and economics, but also "soft" subjects.

- It is of great importance that students become familiar with the tools of the industrial engineering and management engineer, such as project management, improvement of processes, as well as improvement of methods, measurement and evaluation.

- Specialization in core fields in the industrial engineering and management discipline, such as "operation management", enables graduates to be leaders in these areas.

- It is of great importance to integrate small projects over the course of BSc studies, in addition to the final project. This will expose the learners to processes taking place in the business world and provide them with early business experience. 
- One should avoid getting into technical specifications and engineering details that could be confusing or harmful during the decision-making process.

- The organization should be examined at a macro level rather than a micro level.

- Graduates should be able to look at the big picture from the client's perspective, adapting a product to the client's requirements.

- The curriculum should provide graduates with interdisciplinary knowledge, and expand their familiarity with the managerial and economic aspects of business.

- Emphasis should be placed more on a marketing-business view and finding ways of producing a product that can be marketed as quickly as possible, and less on optimization processes.

- As the industrial engineering and management discipline is extensive, many areas should be combined in the training process, and diverse subjects from various disciplines should be taught.

- The curriculum must combine managerial training, knowledge in management and operations, and provide a foundation in mathematical engineering.

- The proximity to social science subjects influences the character of the fields studied in the curriculum.

- The curriculum should be adapted to market requirements and combine a little theory and a lot of practice.

- Alongside those who will be dealing with future managerial positions and will need to know a little about a lot, there are also graduates who will be interfacing with production itself. Therefore, they will have to be very familiar with production processes.

Some of the interviewees referred to the difference between Bachelor's and Masters' degree studies in the industrial engineering and management discipline. They claimed that the curriculum for BSc studies must include a breadth of study or, in other words, teach students to know a little about a lot. The graduate will then enrich their knowledge in the specific specialization of their choice. Studies towards an MSc, focusing on the graduate's area of specialization, will then reflect a focus on depth. Most of the interviewees agreed that the curriculum for a BSc degree in industrial engineering and management should provide graduates with tools that will enable them to enrich their knowledge in their future field of specialization. 
Regarding integration between the various subjects of study, the interviews revealed that a graduate should be trained to carry out integration and synchronization among individuals, and consider different interdisciplinary interfaces. The main points discovered in this context are as follows:

- The graduate requires a systems thinking ability to enable them to see the broad, overall picture. Part of this ability involves discerning what is important and what is not, and making the right decisions based on seeing the big picture. How the decision is made will also affect additional factors in the organization.

- The curriculum must include the study of processes, with an emphasis on systems rather than depth.

- The curriculum that teaches "a little" about "a lot" empowers the learner to develop a systemic view.

- The role of the industrial engineer is to provide a solution at an organizational level, to enable the client to receive the product quickly.

- Graduates should have a broad systemic view: the ability to look at cross-organizational and organization-wide processes, and examine their advantages and disadvantages for the entire organization, as well as the ability to look at the organization's external position.

- An integral part of the industrial engineer's work involves the use of emotional intelligence.

- The advantage of industrial engineering and management graduates is their ability to see systemically, to learn and think independently. Graduates with a process-based, systemic view can be better managers.

- Industrial engineering and management graduates should create links and connections between different systems in an organization.

Linked to the above, the interviewees claimed that the industrial engineering and management curriculum should enable graduates to ask the right questions, but not necessarily understand each specific area in an in-depth fashion:

- The field imparts little knowledge about many areas. What separates the industrial engineer from engineers in other disciplines is their quick, in-depth learning ability with regard to the relevant fields required for their work. 
- It is very important to impart basic knowledge in the areas of electronics, electricity, metals, plastics, machines, materials, and familiarize students with organizational processes. This will help graduates to ask relevant questions when required to make managerial decisions in the organization.

- The curriculum must spark curiosity and encourage independent study among learners.

From the findings presented above, the characteristics of successful industrial engineering engineers may be determined. It may be assumed that very few graduates are endowed with all of the above-mentioned characteristics. The list is generic and may be adapted to the specific requirements of each individual industrial engineer, according to the unique environment in which they work.

In addition, the results highlighted several recommendations, in particular, that the curriculum should be developed in relation to both industrial engineering and management requirements, as well as the demands of the relevant job market. Other recommendations were as follows:

- The curriculum should encourage graduates to integrate into traditional low-tech industries considered to be less attractive.

- "Soft" areas should be included in the industrial engineering and management curriculum, such as organizational consultation, organizational culture, employee motivation, organizational politics and behavioral science, which are all essential for the graduate's successful integration into the job market.

- The curriculum should train junior managers in their preliminary integration into the job market. Therefore, emphasis should be placed on acquiring proper management skills.

- The curriculum should respond to the need to integrate medium- and senior-level graduates.

Finally, the argument was made that part of the industrial engineering and management curriculum was a function of existing academic resources. Despite this, the curriculum must be dynamic and reflect current business processes. The face of the industrial engineering and management discipline has undergone dramatic changes owing to globalization processes. Consequently, great importance is placed on the graduates' ability to build a set of relevant skills within their program of study, while also using resources outside the organization, such as the Internet and rival companies. 


\section{Discussion}

\subsection{Systems thinking: The industrial engineering and management curriculum}

From an analysis of the interviews carried out during this study, most of the interviewees highlighted the importance of systemic aspects of the industrial engineering and management curriculum. According to respondents, the knowledge required of an industrial engineering and management graduate includes practical knowledge, knowledge of processes in systems and methods, processes and approaches for analyzing decision-making problems, and finding solutions. Graduates are frequently required to use knowledge that relates to systemic organizational processes.

According to Bugler (2004), we can expect that the focus on the acquisition of knowledge alone will decline in the future, with emphasis being placed instead on developing the ability to use it. The industrial engineering and management curriculum should enable the student to acquire the ability to use the diverse practical knowledge that develops as a result of thinking and doing.

Chen (1999) describes the transition of the expression of knowledge from a linear model, which is instrumental in building the curriculum in a linear hierarchical fashion, to an expression of knowledge according to complex models. Chen (1999) also describes the transition of knowledge from a static universal expression to a dynamic expression, which stems from the fact that human knowledge is constantly undergoing changes. When implementing these changes in the expression of relevant knowledge in the industrial engineering and management curriculum, emphasis should be placed on the systemic character of some of the study subjects, and the nonlinear complex structure of the curriculum.

When considering the essence of the industrial engineering and management curriculum, in particular in relation to the changes presented above regarding the expression of knowledge, the "learning organization" approach can be of great help (Senge, 1994). Some of the principles of the learning organization approach, which presents organizational learning processes, can be implemented in the design of the industrial engineering and management curriculum. The learning organization approach emphasizes the importance of organizational learning ability, utilizing the knowledge accumulated in the organization and its surroundings and transforming it into acumen to ensure the organization's success (Levy, 2008). Similarly, the industrial engineering and management curriculum should also foster new thinking patterns among students, as well as exposing them to complex processes and connections between actions and systems. This will help students succeed in integrating in the job market upon completion of their studies. 
Senge (1994) emphasizes the development of systems thinking or, in other words, the ability to see and focus on the whole - on patterns rather than parts. In addition, he indicates the importance of learning over time, the ability to constantly understand, criticize and change thinking schemes, the ability to learn and interpret reality according to different basic assumptions, and the ability to abandon old concepts quickly (Levy, 2008). Similarly, many of the interviewees claimed that the industrial engineering and management graduates should be required to use their acquired knowledge as a source of developing new and novel ideas. Therefore, the industrial engineering and management curriculum must promote continuous development and learning, as well as foster cooperation among students, initiatives and innovation. In addition, many interviewees claimed that the curriculum should help develop systems thinking among learners. According to Senge (1994), systems thinking focuses on the organization's constant renewal of its design by developing individual and team-oriented learning skills. Learning takes place through the development of specific skills to discover and understand mutual relations between organizational components and different organizational processes that influence learning and its utilization (Levy, 2008). Similarly, the industrial engineering and management curriculum should also include systems learning that enables students to see the overall picture. An analysis of the different interviews illustrates general agreement on this matter among all the interviewees, who claimed that industrial engineering and management graduates must have a broad systems view, including the ability to examine cross-organizational and organization-wide processes. Interviewees claimed that the students' final project undertaken in their final year of studies enhanced their systems thinking ability.

\section{Conclusions}

From the analysis of the interview findings, several principles may be deduced upon which the industrial engineering and management curriculum should be based:

- An integrative approach should be emphasized in the industrial engineering and management discipline, highlighting a systemic approach in the learning process.

- Theoretical-conceptual knowledge should be combined with practical-experiential knowledge, although the question of "dosage" regarding each type of knowledge remains controversial.

- Engineering principles and familiarization with basic physical processes should be established as a basis for learning.

- Mathematical models should be used to present and solve real problems.

- Students should be exposed to managerial-business-economic aspects, as well as to aspects related to human factors. 
- Quantitative tools that represent part of the fundamental aspects of the field should be implemented and applied.

- The constant development of learning, cooperation among students, initiative, and innovation should be encouraged.

The discussion of the T-shape dilemma, and the design of the industrial engineering and management curriculum as a result of this dilemma, will continue to be an integral part of the work of individuals dealing with curriculum development in academia. One of the findings of this study, which illustrates the importance of the dilemma, is the marked difference between what senior-level managers in industry had to say compared to leading academics regarding the number of hours of academic study required in core fields. The extent to which there is and should be - depth as opposed to breadth in teaching and learning in the field of industrial engineering and management still represents a bone of contention within the community of researchers in this area, and no decisive conclusions have yet been reached; further research must therefore be carried out.

In summary, the industrial engineering and management curriculum must be dynamic, and reflect the up-to-date processes of the business world. The curriculum must expose learners to the world in which capital, production, management, work, markets, technology, and information traverse national borders and affect one another.

Contrary to those who believe that too great an emphasis is placed on the horizontal part of the $T$ shape (breadth) in teaching the industrial engineering and management discipline, many others believe that this field is a body of knowledge in itself, enabling graduates to integrate successfully into defined and significant positions in the business market. 


\section{References}

Alpert, B. (2002). Concepts and ideas in the curriculum as leading texts, values and goals. Reches Educational Projects.

Blum, A. (1991). The knowledge structure and integrating subjects in science education. The Ministry of Education of the State of Israel.

Bugler, R. (2004). Future trends in schools development and its influence on the teacher professional development. Teachers in a world of change: trends and challenges. Open University.

Chen, D. (1999). The future schools. Between theory and practice. Ramot.

Fogarty, R. (1991). Ten ways to integrate curriculum. Educational Leadership, 49(2), 61-65.

Hedlund, G. (1994). A model of knowledge management and the N-Form Corporation. Strategic Management Journal, 15, 73-90. http://dx.doi.org/10.1002/smj.4250151006

Hitt, M., Ireland, R., \& Hoskisson, R. (2001). Strategic management: Competitiveness and globalization. South-Western College.

Levy, A. (2008). Management and leadership: Change and innovation. Rimonim Publishing.

Nonaka, I., \& Takeuchi, H. (1995). The knowledge creating company. Oxford: Oxford University Press.

Sanchez, R., \& Heene, A. (1997). Strategic learning and knowledge management. New York: John Wiley.

Senge, P.M. (1994). The fifth discipline: The art and practice of the learning organization. New York: Doubleday.

Travaslaky, A. (2006). The contribution of the constructivist program to the students - from the mentors' and students' point of view. Oranim College. The Multidisciplinary Education Program. 


\section{Appendix A}

\begin{tabular}{|c|c|c|c|c|c|c|}
\hline No. & $\begin{array}{l}\text { Main } \\
\text { category }\end{array}$ & Subcategory & Interview examples & $\begin{array}{l}\text { Business } \\
\text { Managers }\end{array}$ & Academics & Total \\
\hline 1. & \multirow{10}{*}{$\begin{array}{l}\text { Level of the } \\
\text { manager/ } \\
\text { managemen } \\
t \text { in the } \\
\text { organization }\end{array}$} & $\begin{array}{l}\text { Business } \\
\text { manager }\end{array}$ & $\begin{array}{l}\text { Manager/business management/ } \\
\text { widthwise/view of the business }\end{array}$ & 31 & 0 & 31 \\
\hline 2. & & $\begin{array}{l}\text { Narrow-minded } \\
\text { thinking }\end{array}$ & $\begin{array}{l}\text { Fixed/structured thinking, thinking using } \\
\text { examples/"engineering" thinking/ not } \\
\text { considering the client's needs }\end{array}$ & 19 & 0 & 19 \\
\hline 3. & & $\begin{array}{l}\text { Systemic } \\
\text { aspects }\end{array}$ & $\begin{array}{l}\text { Take into account diverse considerations/all } \\
\text { aspects of the organization/systems } \\
\text { thinking/systems view, combining economic, } \\
\text { legal and marketing aspects related to the } \\
\text { distribution process, development resources } \\
\text { and human resources/a macro-level view }\end{array}$ & 29 & 5 & 34 \\
\hline 4. & & Systemic view & $\begin{array}{l}\text { Integrative view/view of things from different } \\
\text { perspectives/view of the entire } \\
\text { picture/examining existing resources versus } \\
\text { market needs/integrating between } \\
\text { departments and sub-departments/broad } \\
\text { view/dividing attention into several levels/view } \\
\text { of the entire organization as one complex/ } \\
\text { understanding cross-organizational processes } \\
\text { and organization-wide processes/an } \\
\text { integrative view/ understanding the entire } \\
\text { system without going into its details/systems } \\
\text { view/cooperation between industrial and } \\
\text { systems engineering and other engineering } \\
\text { departments (electronics, electricity, } \\
\text { computers)/overall view of processes/holistic } \\
\text { thinking concerning the whole } \\
\text { picture/systems/ability to see the problem, its } \\
\text { implications and ways of solving it }\end{array}$ & 35 & 17 & 52 \\
\hline 5 & & $\begin{array}{l}\text { Organization } \\
\text { management }\end{array}$ & $\begin{array}{l}\text { Organization management versus business } \\
\text { management/management of ongoing } \\
\text { activities }\end{array}$ & 12 & 0 & 12 \\
\hline 6 & & $\begin{array}{l}\text { Engineering- } \\
\text { technological } \\
\text { aspect }\end{array}$ & $\begin{array}{l}\text { Engineering tools/quality control } \\
\text { tools/practical rather than theoretical tools/ } \\
\text { technical operational aspect/engineering } \\
\text { knowledge/engineering part/technological } \\
\text { aspect }\end{array}$ & 21 & 7 & 28 \\
\hline 7 & & $\begin{array}{l}\text { Operational } \\
\text { aspect }\end{array}$ & $\begin{array}{l}\text { Operational engineering decisions/ examining } \\
\text { the operational organizational process }\end{array}$ & 19 & 1 & 20 \\
\hline 8 & & $\begin{array}{l}\text { Managerial } \\
\text { tools }\end{array}$ & $\begin{array}{l}\text { Business administration aspects/ business } \\
\text { administration tools/ marketing tools/business } \\
\text { view }\end{array}$ & 15 & 7 & 22 \\
\hline 9 & & $\begin{array}{l}\text { Thinking } \\
\text { flexibility }\end{array}$ & $\begin{array}{l}\text { Inventive thinking/flexible thinking/ matching } \\
\text { the product to the client }\end{array}$ & 8 & 0 & 8 \\
\hline 10 & & $\begin{array}{l}\text { Initiative and } \\
\text { curiosity }\end{array}$ & $\begin{array}{l}\text { Manager who initiates/is curious/is an } \\
\text { independent learner/identifies new directions }\end{array}$ & 7 & 1 & 8 \\
\hline 11 & & Legal aspect & Legal experience/legal know-how/ contracts & 5 & 0 & 5 \\
\hline 12 & & $\begin{array}{l}\text { Business } \\
\text { thinking }\end{array}$ & $\begin{array}{l}\text { Breadth of training/business thinking/ } \\
\text { business-marketing aspect/maximizing } \\
\text { possibilities/opening markets/representation of } \\
\text { companies/ interpersonal relations/emphasis } \\
\text { on "What to do" rather than "How to do it" }\end{array}$ & 17 & 4 & 21 \\
\hline
\end{tabular}




\begin{tabular}{|c|c|c|c|c|c|c|}
\hline No. & $\begin{array}{l}\text { Main } \\
\text { category }\end{array}$ & Subcategory & Interview examples & $\begin{array}{l}\text { Business } \\
\text { Managers }\end{array}$ & Academics & Total \\
\hline 13 & & $\begin{array}{l}\text { Manager in an } \\
\text { organization }\end{array}$ & $\begin{array}{l}\text { Industrial engineers as business managers in } \\
\text { an organization/department managers/ project } \\
\text { managers }\end{array}$ & 13 & 5 & 18 \\
\hline 14 & & $\begin{array}{l}\text { Interdisciplinary } \\
\text { knowledge }\end{array}$ & Use of interdisciplinary knowledge & 12 & 7 & 19 \\
\hline 15 & & $\begin{array}{l}\text { Decision based } \\
\text { on facts }\end{array}$ & $\begin{array}{l}\text { Taking no chances/making decisions based on } \\
\text { facts }\end{array}$ & 2 & 0 & 2 \\
\hline 16 & & $\begin{array}{l}\text { Manager } \\
\text { involvement }\end{array}$ & Manager's level of involvement & 3 & 0 & 3 \\
\hline 17 & & $\begin{array}{l}\text { Decision based } \\
\text { on feelings }\end{array}$ & $\begin{array}{l}\text { Decision-making based on intuition and } \\
\text { feelings }\end{array}$ & 7 & 0 & 7 \\
\hline 18 & & $\begin{array}{l}\text { Discussion of } \\
\text { the depth of } \\
\text { the process }\end{array}$ & $\begin{array}{l}\text { Depth in engineering/building processes and } \\
\text { projects/getting down to the level of small } \\
\text { items/level of the individual bit/core of the } \\
\text { organization/business expertise/discussion at } \\
\text { a level of profit and loss/emphasis on "How to } \\
\text { do it" rather than "What to do" }\end{array}$ & 13 & 2 & 15 \\
\hline 19 & & $\begin{array}{l}\text { Empathic } \\
\text { manager }\end{array}$ & $\begin{array}{l}\text { Manager who is attentive to the environment } \\
\text { and the employees/ understands an } \\
\text { employee's troubles }\end{array}$ & 6 & 0 & 6 \\
\hline 20 & & $\begin{array}{l}\text { Inherent } \\
\text { managerial } \\
\text { ability }\end{array}$ & Inherent managerial qualities & 11 & 0 & 11 \\
\hline 21 & & $\begin{array}{l}\text { Acquired } \\
\text { systemic view }\end{array}$ & $\begin{array}{l}\text { Systemic view that can be improved, acquired } \\
\text { and learned }\end{array}$ & 11 & 1 & 12 \\
\hline 22 & & $\begin{array}{l}\text { Management of } \\
\text { manufacturing } \\
\text { systems }\end{array}$ & $\begin{array}{l}\text { Production planning and supervision/ following } \\
\text { the product from its initial order to its } \\
\text { execution/building product trees }\end{array}$ & 6 & 0 & 6 \\
\hline 23 & & $\begin{array}{l}\text { Management in } \\
\text { the } \\
\text { organization }\end{array}$ & $\begin{array}{l}\text { Leading in senior-level positions/ organization } \\
\text { management/knowledge management }\end{array}$ & 5 & 2 & 7 \\
\hline 24 & & $\begin{array}{l}\text { Asking } \\
\text { questions }\end{array}$ & $\begin{array}{l}\text { Ability to ask the right questions/know a little } \\
\text { about a lot }\end{array}$ & 10 & 1 & 11 \\
\hline 25 & & $\begin{array}{l}\text { Choosing the } \\
\text { right manager }\end{array}$ & $\begin{array}{l}\text { Connection between the organizational stage } \\
\text { of the organization and choosing the right } \\
\text { manager }\end{array}$ & 2 & 0 & 2 \\
\hline 26 & & $\begin{array}{l}\text { Marketing and } \\
\text { business view }\end{array}$ & $\begin{array}{l}\text { The marketing view as part of the systemic } \\
\text { view: the ability to see the client's } \\
\text { needs/connection to the organization's } \\
\text { goals/connection to the organization's } \\
\text { business needs }\end{array}$ & 4 & 0 & 4 \\
\hline 27 & & Critical factors & $\begin{array}{l}\text { Systemic view enabling identifying bottlenecks } \\
\text { - the critical cause/isolation/ focusing on } \\
\text { critical activities/industrial engineer who } \\
\text { determines what the critical factor } \\
\text { is/determines priorities/identification of } \\
\text { bottlenecks from a broad perspective/broad } \\
\text { view requiring a systemic perspective }\end{array}$ & 17 & 0 & 17 \\
\hline 28 & & $\begin{array}{l}\text { Systemic view } \\
\text { as part of } \\
\text { improved } \\
\text { management }\end{array}$ & Systemic view to improve the manager's work & 3 & 0 & 3 \\
\hline 29 & & $\begin{array}{l}\text { Systemic view } \\
\text { in the } \\
\text { characterization } \\
\text { processes }\end{array}$ & $\begin{array}{l}\text { Systemic view while characterizing and } \\
\text { identifying needs }\end{array}$ & 1 & 0 & 1 \\
\hline 30 & & Curiosity & Curiosity as an essential quality for promotion & 3 & 1 & 4 \\
\hline 31 & & $\begin{array}{l}\text { Charismatic } \\
\text { manager }\end{array}$ & $\begin{array}{l}\text { Charismatic manager/people listen to the } \\
\text { manager/manager's presence is felt/is capable } \\
\text { of harnessing employees to service/is able to } \\
\text { motivate employees/is able to activate others }\end{array}$ & 6 & 0 & 6 \\
\hline
\end{tabular}




\begin{tabular}{|c|c|c|c|c|c|c|}
\hline No. & $\begin{array}{l}\text { Main } \\
\text { category }\end{array}$ & Subcategory & Interview examples & $\begin{array}{l}\text { Business } \\
\text { Managers }\end{array}$ & Academics & Total \\
\hline 32 & & $\begin{array}{l}\text { "Soft" areas in } \\
\text { systems } \\
\text { thinking }\end{array}$ & $\begin{array}{l}\text { Systems thinking that relates to soft areas, } \\
\text { such as interpersonal relations, ability to make } \\
\text { deductions, coping with independent learning }\end{array}$ & 5 & 1 & 6 \\
\hline 33 & & $\begin{array}{l}\text { Depth of job } \\
\text { position }\end{array}$ & $\begin{array}{l}\text { Depth of job position as a focus on knowledge } \\
\text { and control }\end{array}$ & 1 & 0 & 1 \\
\hline 34 & & Learning ability & $\begin{array}{l}\text { Educated manager/manager who } \\
\text { understands/has orientation and integration } \\
\text { ability/has the ability to implement/an } \\
\text { engineer having a learning ability }\end{array}$ & 9 & 7 & 16 \\
\hline 35 & & $\begin{array}{l}\text { Breadth of } \\
\text { learning }\end{array}$ & Managerial position/knows a little about a lot & 9 & 3 & 12 \\
\hline 36 & & $\begin{array}{l}\text { Discerning what } \\
\text { is important } \\
\text { and what is not }\end{array}$ & $\begin{array}{l}\text { Ability to make the right decision/discerns } \\
\text { what is important and what is not/systems } \\
\text { thinking as being an integral part of the } \\
\text { manager's work }\end{array}$ & 7 & 0 & 7 \\
\hline 37 & & $\begin{array}{l}\text { Emotional } \\
\text { intelligence }\end{array}$ & $\begin{array}{l}\text { Management that incorporates emotional } \\
\text { intelligence }\end{array}$ & 3 & 1 & 4 \\
\hline 38 & & $\begin{array}{l}\text { Cognitive } \\
\text { aspect }\end{array}$ & $\begin{array}{l}\text { Cognitive field: ability to analyze situations } \\
\text { and make decisions }\end{array}$ & 0 & 3 & 3 \\
\hline 39 & & $\begin{array}{l}\text { Experienced } \\
\text { manager }\end{array}$ & $\begin{array}{l}\text { Manager/industrial engineering engineer who } \\
\text { develops himself and grows through } \\
\text { accumulated personal and professional } \\
\text { experience }\end{array}$ & 13 & 3 & 16 \\
\hline 40 & $\begin{array}{l}\text { Level of the } \\
\text { organization }\end{array}$ & $\begin{array}{l}\text { Traditional vs. } \\
\text { advanced } \\
\text { industries }\end{array}$ & $\begin{array}{l}\text { Recruiting industrial engineers in low-tech as } \\
\text { opposed to high-tech industries and in banking } \\
\text { and finance }\end{array}$ & 6 & 3 & 9 \\
\hline 41 & & Time to market & Time to market & 3 & 0 & 3 \\
\hline 42 & & $\begin{array}{l}\text { Marketing } \\
\text { aspect }\end{array}$ & $\begin{array}{l}\text { Center of gravity is in marketing rather than } \\
\text { development/the company's existence } \\
\text { depends on the number of business deals }\end{array}$ & 3 & 0 & 3 \\
\hline 43 & & $\begin{array}{l}\text { Systemic view } \\
\text { as part of the } \\
\text { organization's } \\
\text { goals }\end{array}$ & $\begin{array}{l}\text { Systemic view connected to the organization's } \\
\text { view/to the organization's goals/the need for } \\
\text { compromise }\end{array}$ & 2 & 0 & 2 \\
\hline 44 & & $\begin{array}{l}\text { Operational } \\
\text { aspect }\end{array}$ & Operational activities & 1 & 1 & 2 \\
\hline 45 & $\begin{array}{l}\text { Level of the } \\
\text { student }\end{array}$ & $\begin{array}{l}\text { Specialization } \\
\text { at work }\end{array}$ & $\begin{array}{l}\text { Graduate on-the-job } \\
\text { training/internship/enrichment in the field of } \\
\text { specialization/in-depth learning }\end{array}$ & 12 & 5 & 17 \\
\hline 46 & & $\begin{array}{l}\text { Integrating } \\
\text { graduates into } \\
\text { the market }\end{array}$ & $\begin{array}{l}\text { Helping graduates integrate into the job } \\
\text { market/graduate growth/practical } \\
\text { training/integration into a medium-level } \\
\text { position in the short term and a future senior- } \\
\text { level position/integrating graduates into all } \\
\text { fields (services and industry) }\end{array}$ & 11 & 5 & 16 \\
\hline 47 & & $\begin{array}{l}\text { Independent } \\
\text { learning }\end{array}$ & $\begin{array}{l}\text { Closing gaps in the world of relevant } \\
\text { knowledge/independent learning of the main } \\
\text { concept and idea/learning from } \\
\text { competitors/learning from knowledge pools }\end{array}$ & 6 & 4 & 10 \\
\hline 48 & & Research ability & $\begin{array}{l}\text { Graduates with research ability/ability to } \\
\text { understand research articles based on } \\
\text { considerable knowledge in a certain area }\end{array}$ & 0 & 5 & 5 \\
\hline 49 & & $\begin{array}{l}\text { Personality } \\
\text { qualities }\end{array}$ & $\begin{array}{l}\text { Personal qualities as an essential part of the } \\
\text { graduate's success in the market/the } \\
\text { interpersonal relations field/motivation to } \\
\text { succeed }\end{array}$ & 0 & 12 & 12 \\
\hline 50 & $\begin{array}{l}\text { Level of the } \\
\text { curriculum }\end{array}$ & $\begin{array}{l}\text { Theoretical } \\
\text { aspect }\end{array}$ & $\begin{array}{l}\text { Dealing too much with theory as opposed to } \\
\text { practice }\end{array}$ & 3 & 1 & 4 \\
\hline
\end{tabular}




\begin{tabular}{|c|c|c|c|c|c|c|}
\hline No. & $\begin{array}{l}\text { Main } \\
\text { category }\end{array}$ & Subcategory & Interview examples & $\begin{array}{l}\text { Business } \\
\text { Managers }\end{array}$ & Academics & Total \\
\hline 51 & & $\begin{array}{l}\text { Business-reality } \\
\text { aspect }\end{array}$ & $\begin{array}{l}\text { Matching the curriculum to the market } \\
\text { needs/exposure to the market and the } \\
\text { business world/connection to the business } \\
\text { reality/business aspects }\end{array}$ & 9 & 8 & 17 \\
\hline 52 & & $\begin{array}{l}\text { Breadth in } \\
\text { relation to } \\
\text { profession }\end{array}$ & $\begin{array}{l}\text { The industrial and systems engineering } \\
\text { profession is not a pure engineering } \\
\text { profession/broad learning/broad } \\
\text { profession/proximity to social sciences }\end{array}$ & 19 & 14 & 33 \\
\hline 53 & & Broad learning & $\begin{array}{l}\text { Bachelor's degree curriculum that enables } \\
\text { knowing a little about a lot }\end{array}$ & 14 & 6 & 20 \\
\hline 54 & & $\begin{array}{l}\text { Expanding the } \\
\text { curriculum }\end{array}$ & $\begin{array}{l}\text { Curriculum that provides tools enabling future } \\
\text { expansion/expansion through elective } \\
\text { courses/expansion in a specific expertise }\end{array}$ & 5 & 6 & 11 \\
\hline 55 & & $\begin{array}{l}\text { Systems } \\
\text { thinking } \\
\text { training }\end{array}$ & $\begin{array}{l}\text { Systems thinking training for industrial } \\
\text { engineering engineers to think systemically }\end{array}$ & 10 & 1 & 11 \\
\hline 56 & & Practical tools & $\begin{array}{l}\text { Importance of learning about practical } \\
\text { tools/Excel/flow charts }\end{array}$ & 3 & 1 & 4 \\
\hline 57 & & $\begin{array}{l}\text { Curriculum } \\
\text { matched to } \\
\text { resources }\end{array}$ & $\begin{array}{l}\text { Planning the curriculum according to existing } \\
\text { resources in academia }\end{array}$ & 1 & 1 & 2 \\
\hline 58 & & $\begin{array}{l}\text { General } \\
\text { learning }\end{array}$ & $\begin{array}{l}\text { Learning culture in the country is faster than } \\
\text { abroad (all-inclusive Bachelor's degree) }\end{array}$ & 1 & 0 & 1 \\
\hline 58 & & $\begin{array}{l}\text { Behavioral } \\
\text { sciences }\end{array}$ & $\begin{array}{l}\text { Combining "soft" areas in the curriculum: } \\
\text { organizational consultation, organization and } \\
\text { methods, organizational culture, employee } \\
\text { motivation, organization politics, behavioral } \\
\text { sciences }\end{array}$ & 4 & 2 & 6 \\
\hline 60 & & $\begin{array}{l}\text { Managerial } \\
\text { training }\end{array}$ & $\begin{array}{l}\text { Managerial training/management as a } \\
\text { profession }\end{array}$ & 7 & 6 & 13 \\
\hline 61 & & $\begin{array}{l}\text { Depth versus } \\
\text { breadth }\end{array}$ & $\begin{array}{l}\text { Combining depth with breadth/breadth of } \\
\text { practice and in-depth research/in-depth study } \\
\text { of the production systems field as opposed to } \\
\text { breadth of study of operational subjects, } \\
\text { information systems, human resources, } \\
\text { quality/gaining an overall picture of these } \\
\text { subjects, as well as the basics of engineering } \\
\text { subjects, such as electricity, mechanical } \\
\text { engineering/exposure that trains graduates to } \\
\text { be integrated into diverse positions/enabling } \\
\text { communication with engineers from other } \\
\text { disciplines/general breadth of learning and } \\
\text { depth of learning at the practical internship } \\
\text { stage/depth of learning as part of the } \\
\text { complete puzzle }\end{array}$ & 1 & 14 & 15 \\
\hline 62 & & $\begin{array}{l}\text { Process } \\
\text { management }\end{array}$ & $\begin{array}{l}\text { Organizational processes engineering/ process } \\
\text { management/project process management }\end{array}$ & 3 & 3 & 6 \\
\hline 63 & & $\begin{array}{l}\text { Industrial and } \\
\text { systems } \\
\text { engineering } \\
\text { tools }\end{array}$ & $\begin{array}{l}\text { Organizational tools to improve organizational } \\
\text { processes/tools from the industrial and } \\
\text { systems engineering discipline (project } \\
\text { management, improvement of methods, } \\
\text { improvement of processes, measurement and } \\
\text { control) }\end{array}$ & 7 & 9 & 16 \\
\hline 64 & & Core areas & $\begin{array}{l}\text { Core fields: production planning and } \\
\text { supervision/production systems/core } \\
\text { areas/industrial engineers responsible for core } \\
\text { processes }\end{array}$ & 3 & 2 & 5 \\
\hline 65 & & $\begin{array}{l}\text { Industrial } \\
\text { engineer } \\
\text { improves the } \\
\text { organization's } \\
\text { performance }\end{array}$ & $\begin{array}{l}\text { Industrial engineer provides a response to a } \\
\text { solution at an organizational level/ensures that } \\
\text { the product is provided to the client in a timely } \\
\text { fashion/helps meet the organization's } \\
\text { goals/improves the organization's } \\
\text { performance/proposes a set of measures }\end{array}$ & 10 & 2 & 12 \\
\hline
\end{tabular}




\begin{tabular}{|c|c|c|c|c|c|c|}
\hline No. & $\begin{array}{l}\text { Main } \\
\text { category }\end{array}$ & Subcategory & Interview examples & $\begin{array}{l}\text { Business } \\
\text { Managers }\end{array}$ & Academics & Total \\
\hline 66 & & $\begin{array}{l}\text { Industrial } \\
\text { engineer in a } \\
\text { systems } \\
\text { position }\end{array}$ & $\begin{array}{l}\text { Industrial engineer connects between } \\
\text { systems/integrates into a systems } \\
\text { position/advantage of lack of familiarity with } \\
\text { subjects in an in-depth fashion/poor } \\
\text { resolution/industrial engineer as a project } \\
\text { manager who uses systems thinking/manager } \\
\text { who synchronizes different } \\
\text { disciplines/industrial engineer who provides } \\
\text { the optimal solution/deals with financial } \\
\text { planning and timetable planning/has added } \\
\text { value }\end{array}$ & 18 & 5 & 23 \\
\hline 67 & & $\begin{array}{l}\text { Diversity of the } \\
\text { profession }\end{array}$ & $\begin{array}{l}\text { Industrial and systems engineering profession } \\
\text { as a diverse profession }\end{array}$ & 7 & 8 & 15 \\
\hline 68 & & $\begin{array}{l}\text { Curiosity and } \\
\text { independent } \\
\text { learning ability }\end{array}$ & $\begin{array}{l}\text { Industrial and systems engineering curriculum } \\
\text { arouses curiosity, and the ability for } \\
\text { independent learning/teaches the student to } \\
\text { learn/to think quantitatively/know how to } \\
\text { model a problem }\end{array}$ & 10 & 5 & 15 \\
\hline 69 & & $\begin{array}{l}\text { Studying the } \\
\text { bottleneck } \\
\text { problem in an } \\
\text { in-depth } \\
\text { fashion }\end{array}$ & Studying the bottleneck problem in depth & 2 & 0 & 2 \\
\hline 70 & & $\begin{array}{l}\text { Practical } \\
\text { curriculum }\end{array}$ & $\begin{array}{l}\text { Curriculum aimed at the market and business } \\
\text { needs }\end{array}$ & 0 & 4 & 4 \\
\hline 71 & & $\begin{array}{l}\text { Technological } \\
\text { basis }\end{array}$ & $\begin{array}{l}\text { Curriculum that does not provide a } \\
\text { technological basis/adding technological } \\
\text { subjects to the curriculum }\end{array}$ & 0 & 3 & 3 \\
\hline 72 & & $\begin{array}{l}\text { Knowing a lot } \\
\text { about a lot }\end{array}$ & $\begin{array}{l}\text { Knowing a lot about a lot/deepening the } \\
\text { horizontal part of the T shape }\end{array}$ & 0 & 4 & 4 \\
\hline 73 & & $\begin{array}{l}\text { Theoretical } \\
\text { basis }\end{array}$ & $\begin{array}{l}\text { Training based on principles rather than } \\
\text { tools/providing a theoretical basis }\end{array}$ & 0 & 5 & 5 \\
\hline 74 & & $\begin{array}{l}\text { Enriching basic } \\
\text { subjects }\end{array}$ & $\begin{array}{l}\text { Enriching basic subjects, such as statistics and } \\
\text { operations research }\end{array}$ & 0 & 3 & 3 \\
\hline 75 & & $\begin{array}{l}\text { Up-to-date } \\
\text { curriculum }\end{array}$ & $\begin{array}{l}\text { Dynamic updating of curriculum/adding the } \\
\text { subject of service to the curriculum }\end{array}$ & 0 & 2 & 2 \\
\hline 76 & & $\begin{array}{l}\text { Understanding } \\
\text { the rationale }\end{array}$ & $\begin{array}{l}\text { Understanding the rationale behind the tool } \\
\text { learned/understanding why the tool is needed } \\
\text { and what is checked when using it }\end{array}$ & 0 & 3 & 3 \\
\hline 77 & & Ability to think & $\begin{array}{l}\text { Systems thinking as part of all components of } \\
\text { intelligence/ability to think }\end{array}$ & 0 & 2 & 2 \\
\hline
\end{tabular}

Table 1A. Summary of interview categories regarding the T-shape dilemma

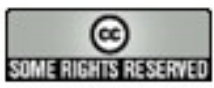

Article's contents are provided on a Attribution-Non Commercial 3.0 Creative commons license. Readers are allowed to copy, distribute and communicate article's contents, provided the author's and Journal of Industrial Engineering and Management's names are included.

It must not be used for commercial purposes. To see the complete license contents, please visit http://creativecommons.org/licenses/by-nc/3.0/. 